book review

\title{
Forgetting Richard Hoggart
}

\author{
K.K. RUTHVEN \\ UNIVERSITY OF ADELAIDE
}

Michael Bailey, Ben Clarke and John K. Walton

Understanding Richard Hoggart: A Pedagogy of Hope

Wiley-Blackwell, Chichester, West Sussex, UK and Malden, MA, 2012

ISBN 9781405194945

RRP AU $\$ 44.95$

Why should people working in twenty-first century cultural studies feel obliged to understand Richard Hoggart? Principally, I suppose, because he institutionalised the umbrella term they still operate under when, as a newly appointed professor of English literature, he persuaded the University of Birmingham to establish in 1964 the very first Centre for Contemporary Cultural Studies (CCCS), with himself as director. Universal gratitude for that initiative, however, is moderated by misgivings about what he personally contributed to the institutional space he'd created, in which other scholars began doing very different kinds of interdisciplinary work from his own. It's commonly acknowledged that cultural studies as now practised didn't gain momentum until that middle-class Jamaican intellectual he'd appointed in 1966 as his deputy, Stuart Hall, became director of the CCCS three years later, and 
strengthened its alliance with New Left politics by incorporating Althusserian ideology and Gramscian hegemony into its analytical lexicon.

The complexity of what goes on globally nowadays under the banner of cultural studies makes it impossible to specify a common origin for that loose federation of varyingly commensurate practices which constitute this ever-expanding and antidisciplinary discipline. That shouldn't worry anybody persuaded by structuralism's synchronic critique of the diachronic cult of origins. Pyramids of knowledge don't rest on foundations, Jean Piaget argued, but are instead suspended from their apexes, where cutting-edge researchers specify the precursors who legitimate their activities. ${ }^{1}$ If you're working on the Downton Abbey phenomenon, for instance, you may think it plausible to acknowledge Hoggart's contribution to your intellectual genealogy. But your elective lineage will be different if you're investigating computer wargames, and different again if your research focuses on mosh-pit etiquette. This will be worth remembering when the fiftieth anniversary of the CCCS comes up in 2014 and the centenary of Hoggart's birth in 2018.

The best-selling book that was to make Hoggart chairworthy in Birmingham was published when I was an undergraduate studying English language and literature at the University of Manchester: The Uses of Literacy: Aspects of WorkingClass Life, with Special Reference to Publications and Entertainments. ${ }^{2}$ I was enthralled by its autobiographically vivid evocations of a labouring-class way of life not unlike the one I was currently extricating myself from. Thanks to support from his local education authority, Hoggart had become a scholarship boy long before Winston Churchill's most radical minister, R.A. Butler, persuaded a Conservative government to pass that 1944 Education Act which enabled thousands of labouringclass children like me to become scholarship boys (even if they were girls) and to attend grammar schools free of charge provided they cleared a hurdle called the Eleven-Plus examination. Life was easier for us than it had been for Hoggart because we were beneficiaries of the welfare state established by the 1945 Labour government.

The only part of The Uses of Literacy that puzzled me was its subsequently famous pages entitled 'Scholarship Boy'. (238-49) Lodged in a chapter on 'the uprooted and the anxious', they represented me and my kind as an emotionally damaged demographic torn 'between two worlds, the worlds of school and home'. 
(242) None of the aspiring meritocrats I mingled with exhibited symptoms of that disability. The principal problem faced at that time by labouring-class children with upwardly mobile ambitions was not the society they'd come out of but the one they were moving into, which was likely to consider them 'scum' because that's what W. Somerset Maugham had called the 'white-collar proletariat' depicted in Kingsley Amis's more-will-mean-worse novel, Lucky Jim (1954), who had 'go[ne] to the universities ... on a Government grant' not 'to acquire culture but to get a job'. ${ }^{3}$ Convinced in those pre-Beatles days that I'd need to get out to get on, I said goodbye to all that as soon as possible by becoming an assistant lecturer in New Zealand. Hoggart, meanwhile, stayed in England to continue enlightening the educationally underprivileged both directly as a teacher and writer and indirectly through his contributions to quangos like the Pilkington Committee on Broadcasting. Feeling uprooted and anxious didn't prevent that hard-working scholarship boy in Leeds from becoming a university professor in Birmingham, an assistant director-general of UNESCO in Paris, and the warden of Goldsmiths College in the University of London.

The Uses of Literacy frames the politics of culture much more personally than those other foundational texts of British cultural studies, Raymond Williams's Culture and Society 1780-1950 (1958) and The Long Revolution (1961), and E.P. Thompson's The Making of the English Working Class (1963). Hoggart's nostalgiafuelled fascination with the pre-war labouring-class north-of-England culture he'd grown up in contrasted sharply with his antipathy to subsequent developments there. As a demobbed artillery officer employed in the University of Hull's extramural program he couldn't understand why young people trapped in postwar austerities and yearning for something more exciting than their parents' notion of a nice night out might enjoy the counter-cultural experience of sitting in neon-lit milkbars listening to juke-box recordings of Bill Haley and His Comets rocking around the clock. The intensity of Hoggart's little-Englander contempt for the Americanisation of British youth culture was reminiscent of wartime animosity towards those 'over-paid' and 'over-sexed' American troops with seductively Hollywood accents, whose fraternisation with English women while 'over here' in the run-up to D-Day was memorialised in thousands of pregnancies. 
Hoggart's judgemental remarks on juke-box boys reveal not only how illequipped he was at this stage to analyse dispassionately cultural developments he disapproved of but also the hazards of basing value judgments on lived experience. Wholly dependable when analysing the insidious ubiquity of British classdistinctions, Hoggart's personal experience was an inadequate guide through the cultural upheavals of the 1960s. Acculturated in a language whose masculine pronoun erased femaleness by putatively including it, he was unprepared for the feminist revelation that gender is a crucial determinant in the production, circulation and consumption of cultural phenomena. Nothing in his formative years prompted him to notice that there ain't no black in the Union Jack. And the only oddity in his heteronormative behaviour has been his lifelong fascination with the poetry of W.H. Auden, which in 1951 became the subject of his first book and in 2005 supplied the title of what he feared would be his last.4 Two equally unanticipated developments revealed the limitations of his print-centred notion of culture. One was the turn to continental and especially French critical theory, which marginalised his own grounding of cultural critique in the close reading of literary texts, a method he'd learned from Q.D. Leavis's Fiction and the Reading Public (1932) and her husband F.R. Leavis's New Bearings in English Poetry (1932) and Revaluation (1936). The other development was the publication in 1962 of Marshall McLuhan's The Gutenberg Galaxy, which predicted the demise of 'typographic man' in a then emergent and now global electronic age. Its multimedia forms have created more urgent agendas for cultural analysts than Hoggart's grand plan for giving labouring-class people what he considered to be their birthright: namely, the opportunity to enrich their lives by reading literary classics, which allegedly warehouse what Matthew Arnold called 'the best that is known and thought in the world'. 5 That experience, Hoggart believed, would give everybody the necessary touchstones for assessing popular culture.

By the time Birmingham established its CCCS I'd been teaching canonical English literature in New Zealand since 1961. Hooked on literary studies in general, and in those days on Anglo-American modernist poetry in particular, I'd no desire to participate in what I took to be the complementary and revolutionary enterprise of examining popular culture as rigorously as elite culture. Persuading others to take it seriously enough to become involved in it, however, wasn't easy. Wags who knew 
that whatever comes out of Birmingham is Brummagem said that cultural studies had been invented to give sociologists something to look down on, an allegation confirmed when Hoggart gave by invitation a paper at a conference of academic sociologists and found himself treated 'like a mongrel among thoroughbred bulldogs'. 6

I encountered a different ambience on relocating in 1980 to Australia, whose home-grown variety of cultural studies sustained the inaugural issue in May 1983 of the Australian Journal of Cultural Studies. Would its formation have been different, I wonder, if Hoggart had declined the UNESCO opportunity in 1969 and responded positively to the University of Queensland's contemporaneously expressed interest in appointing him as its vice-chancellor? I should confess that my desire to see cultural studies mainstreamed institutionally instead of confined to some of the newer Australian universities and CAEs was not merely altruistic. I believed that post-Leavisite English studies could be reinvigorated by applying methodologies pioneered in cultural studies to the category of writing known as literature. So did many other people: recent investigations into the cultural afterlives of remediated literary classics, for instance, owe their existence knowingly or otherwise to politically inflected demonstrations in the domain of cultural studies of the ways in which cultural products are consumed and processed for different purposes at different times by different constituencies. Such developments have reversed Hoggart's original intention to improve cultural studies by injecting literary criticism into it.

After opening up Southern Review editorially to cultural studies, I aimed to get it recognised by the Australian Academy of the Humanities, which at that time was unable to honour any scholar whose research couldn't be siloed into one of its nine electoral categories: Asian Studies; Classical Studies; English; European Literature and Philology; Fine Arts; History; Linguistics and Philology; Philosophy, Religion, and History of Ideas; and Prehistory and Archaeology. A conference on the new humanities I persuaded the Academy to host in 1991 included papers on both cultural studies and cultural policy studies. In diplomatic parlance its reception was mixed; but it kick-started the process that culminated in 1997 with the induction of inaugural fellows into a new electoral section called Cultural and Communication Studies. $^{7}$ Seven years later, what I'd believed impossible actually happened: in 
December 2004 the Academy elected one of its CCS fellows, Graeme Turner, as its next president.

In the longue durée of his varied career, Hoggart's years at the CCCS came to look increasingly like a busy distraction from what he really wanted to do: 'the current Follies at the Centre you founded', Thompson commiserated in 1977, 'must make you want to throw up'. (101) Hoggart needs to be taken seriously not on account of his dwindling relevance to contemporary cultural studies but because he was an influential public intellectual in late twentieth-century Britain. Like its predecessors-The Uses of Richard Hoggart (2007) and Richard Hoggart and Cultural Studies (2008)-Understanding Richard Hoggart is enriched by previously unpublished trouvailles culled from the eighty-two boxes of papers lodged in the University of Sheffield's Hoggart Archive. 8 Various sections of Understanding Richard Hoggart illuminatingly historicise both his engagements and failures to engage with the disciplinary domains he trespassed into. Hoggart's 'essential commitment', we are informed, 'was to a marriage between literary studies and sociology (together with anthropology and social psychology)'; (107) he 'never developed ... a sense of historical understanding and processes beyond the mode of reflexive autobiography'. (109) The negative tone of such astute judgements is strikingly at odds with the principal intent of this book, which is to recuperate Hoggart's writings for 'a pedagogy of hope'. The humanities could rediscover the mission they lost while whoring after strange theorists, we're asked to believe, by reviving a Hoggartian humanism whose dominant values are 'right judgement', 'moral authority', 'plain speech', 'fair-mindedness', 'civility', 'common decency', and 'compassion'. (200) Armed with these values, we could 'intervene' productively 'in current debates on ... class and culture, education and the arts'. (2) In the transnationally corporatised world that houses 'the university in ruins' I can't imagine a more hopeless use of Hoggart's wide-ranging writings. ${ }^{9}$

K.K. Ruthven is an emeritus professor of the University of Melbourne and a visiting professor at the University of Adelaide, where he is collaborating with T.L. Burton on an Oxford University Press edition in three volumes of The Complete Poems of William Barnes. 


\section{-NOTES}

${ }^{1}$ Jean Piaget, Structuralism, trans. and ed. Channah Maschler, Routledge and Kegan Paul, London, 1971, p. 34 .

2 Richard Hoggart, The Uses of Literacy: Aspects of Working-Class Life, with Special Reference to Publications and Entertainments, Chatto and Windus, London, 1957.

3 Somerset Maugham, 'Books of the Year', Sunday Times, 25 December 1955; quoted in Zachary Leader, The Life of Kingsley Amis, Jonathan Cape, London, 2006, pp. 356-7.

${ }^{4}$ Richard Hoggart, Auden: An Introductory Essay, Chatto and Windus, London, 1951; Richard Hoggart, Promises to Keep: Thoughts in Old Age, Continuum, London, 2005.

5 Matthew Arnold, Essays in Criticism, Macmillan, London, 1865, p. 39.

${ }^{6}$ Hoggart, Promises to Keep, p. 75.

7 K.K. Ruthven (ed.), Beyond the Disciplines: The New Humanities, Australian Academy of the Humanities, Canberra, 1992.

${ }^{8}$ Sue Owen and John Hartley (ed.), 'The Uses of Richard Hoggart', International Journal of Cultural Studies, vol. 10, no. 1, March 2007; Sue Owen (ed.), Richard Hoggart and Cultural Studies, Palgrave Macmillan, Basingstoke, 2008.

9 See Bill Readings, The University in Ruins, Harvard University Press, Cambridge, MA, 1996. 